\title{
Table of statutory texts
}

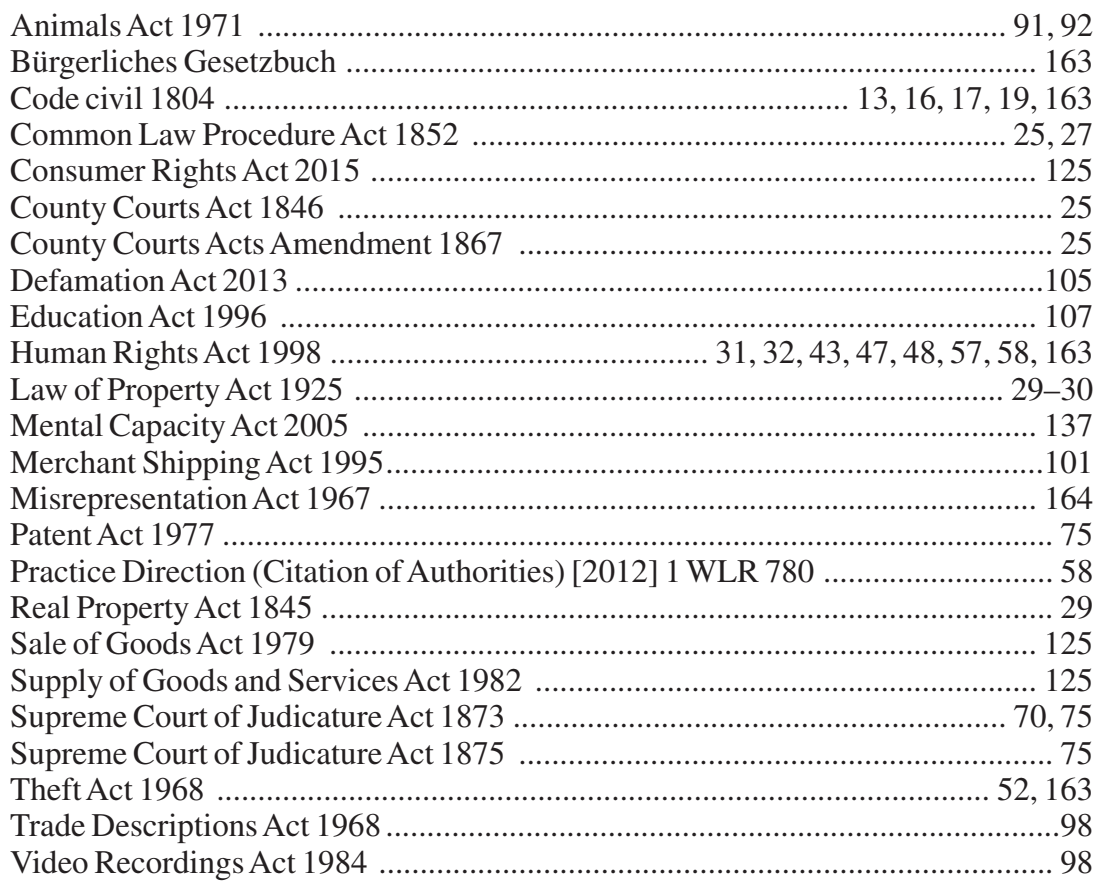


Geoffrey Samuel - 9781785365928 Downloaded from PubFactory at 04/26/2023 10:02:27AM via free access 